\title{
Molecular analysis of the AGXT gene in Syrian patients suspected with primary hyperoxaluria type 1
}

\author{
Hossam Murad ${ }^{1 *}$, Mohamad Baseel Alhalabi ${ }^{1}$, Amir Dabboul ${ }^{1}$, Nour Alfakseh', Mohamad Sayah Nweder ${ }^{1}$,
} Youssef Zghib² and Hala Wannous ${ }^{2}$

\begin{abstract}
Background: Characterization of the molecular basis of primary hyperoxaluria type 1 ( $\mathrm{PH}-1$ ) in Syria has been accomplished through the analysis of 90 unrelated chromosomes from 45 Syrians patients with $\mathrm{PH}-1$ from different regions.

Methods: Alanine glyoxylate aminotransferase (AGXT) gene mutations have been analyzed by using molecular detection methods based on the direct DNA sequencing for all exons of the AGXT gene.

Results: Seventeen pathogenic mutations were detected in our patients. Six mutations were novels. The three most frequent mutations were c.33_34insC (p.Lys12fs) in Exon 1, c.584 T<G; p.Met195Arg in exon 5 and c.1007 T>A (p.Val336Asp) in exon 10, with a frequency of $33.3 \%, 12.2 \%$, and $11.1 \%$, respectively.
\end{abstract}

Conclusion: DNA sequencing used in this study can offer a useful method to investigate the mutations in Syrian $\mathrm{PH}-1$ patients, and could offer an accurate tool for prenatal diagnosis and genetic counseling.

Keywords: Primary hyperoxaluria type 1, AGXT, Syria

\section{Background}

Primary hyperoxaluria $(\mathrm{PH})$ is a recessive inherited inborn error of glyoxylate metabolism. The estimated prevalence of $\mathrm{PH}$ is $1-3$ per $1,000,000$ individuals [1]. Formerly, three subgroups are well known within $\mathrm{PH}$. Primary hyperoxaluria type 1 (PH-1; MIM 259900) is an autosomal recessive and inherited disorder. It considered as the most severe form of PH. It is caused by mutations in alanine glyoxylate aminotransferase (AGXT) gene encode the alanine: glyoxylate aminotransferase (AGT) enzyme (AGT; EC2.6.1.44) [2].

The absence of the enzyme AGT leads to the conversion of glyoxylate to oxalates, and thus causes an increase

\footnotetext{
*Correspondence: ascientific@aec.org.sy

1 Human Genetics Division, Molecular Biology and Biotechnology Department, Human Genetics Division, Atomic Energy Commission of Syria, P.O. Box 6091, Damascus, Syria

Full list of author information is available at the end of the article
}

in blood oxalate levels (hyperoxalemia) as well as urine oxalate levels (hyperoxaluria) with large deposits of calcium oxalate in the kidneys and other organs [3]. While, the deficiency of glyoxylate and hydroxypyruvate reductase, which is encoded by GRHPR, is responsible for primary hyperoxaluria type $2(\mathrm{PH}-2)$. Primary hyperoxaluria type $3(\mathrm{PH}-3)$ is caused by mutations in HOGA1. This gene encodes the mitochondrial enzyme, 4-hydroxy2-oxoglutarate aldolase (HOGA) which catalyzes the 4-hydroxy-2-oxoglutarate to glyoxylate and pyruvate [4, 5].

Patients with $\mathrm{PH}-1$ have variable clinical features at presentation, like, urinary tract infections abdominal pain, recurrent hematuria, nephrolithiasis, nephrocalcinosis and end-stage renal disease (ESRD) [5]. Age at onset of symptoms typically varies from 1 to 25 years. About, $20-50 \%$ of patients have advanced chronic kidney 
disease (CKD) or even end stage renal disease (ESRD) at the time of diagnosis $[6,7]$.

AGXT present in two haplotypes: Major allele (Maj) and Minor allele (Min). The minor allele have three polymorphisms: Proline to leucineat residue 11 (P11L) in exon 1, Isoleucine to Methionine at residue 340 (I340M) in exon 10 and 74 bp duplication in intron 1. Major allele is present about $100 \%$ in the peroxisome, while the minor allele is present about $95 \%$ in the peroxisome and 5\% in the mitochondria [8]. The polymorphic variants are found in linkage disequilibrium with the minor allele haplotype, whereas the absence of these polymorphisms defines the major allele.

AGXT gene is located on chromosome 2 (2q37.3) and spans about $10 \mathrm{~kb}$ DNA. The protein of this gene consists of 392-amino-acid (43 kDa). Mutations in the AGXT gene moderated the $\mathrm{PH}-1$ phenotype. To date, there are more than 200 mutations that have been described as causing the disease according to the Human Gene Mutation Database (HGMD) (http://www.hgmd.cf.ac. uk). Seventy-five percent of these mutations are classified as point mutations (nonsense, missense, and nucleotide changes affecting splice-site consensus sequences). While, $25 \%$ of these mutations are detected as minor or major deletions and insertions [6].

In this study, we performed sequence analyses of AGXT gene to characterize the mutational spectrum of $\mathrm{PH}-1$ in Syrian patients.

\section{Methods \\ Patients}

A total of 45 unrelated patients with $\mathrm{PH}-1$ deficiency from different regions from Syria, corresponding to 90 independent alleles, were enrolled in this study. The average age of patients at referral was 7.18 years, ranging between 3 months and 45 years. Clinical manifestations of the patients with $\mathrm{PH}$ was based on (nephrocalcinosis, urolithiasis and end-stage renal failure), urinalysis (raised oxalate) and elevated plasma oxalate in combination with spectrophotometric analysis of the calculation (Table 1).

\section{DNA isolation and sequencing}

Blood samples $(3 \mathrm{ml})$ were collected from each patient by venipuncture in EDTA. Genomic DNA was isolated from peripheral blood using the QIAamp DNA Blood Mini Kit (Qiagen, Inc.) according to manufacturer's instructions. All exons and flanking regions of the AGXT gene were amplified by PCR and screened for mutations by direct sequencing as previously reported [9]. Obtained sequences were aligned to the AGXT reference genomic sequence (GenBank: NM_000030.2).

\section{Ethical approval}

The parents of the minor patient and all adult patients, provided informed consent to the diagnostic and therapeutic procedures involved, in agreement with the guidelines approved by our institutional clinical research ethics committee.

\section{Result}

\section{Clinical data of $\mathrm{PH}-1$ patients}

Our study was composed of 45 unrelated $\mathrm{PH}-1$ patients from different regions of Syria: twenty-five patients $(55.55 \%)$ were female and twenty $(44.44 \%)$ were male. The parents of $75 \%$ of these patients had blood relation (positive consanguinity). Twenty-three of 45 patients (51.1\%) had a positive family history of renal stone (Table 1 ).

\section{Identification of mutations}

Molecular diagnosis was performed at first by DNA direct sequencing of exons 1, 2, 5, 7 and 10 in order to investigate the common mutations reported in Arab population [10-13]. In heterozygous and negative patients for tested exons, we performed a molecular analysis of the remaining exons of AGXT gene.

Analysis of the coding regions and flanking intronic sequences of the AGXT gene shows the presence of seventeen different mutations in 45 patients (Fig. 1).

Thrifty-four patients (75.5\%) had disease causing homozygous mutations; eight patients (17.7\%) had disease causing compound heterozygous mutations. Three additional individuals were found to be carriers of the one mutation (Table 1).

The most frequent mutation carried by our patients was the c.33_34insC (p.Lys12fs) in exon 1 with an allele frequency equal to $33.3 \%$. The second most frequent mutation was $\mathrm{T}$ to $\mathrm{G}$ substitution at position 584 (c.584 $\mathrm{T}<\mathrm{G}$; p.Met195Arg) with allele frequency, $12.2 \%$. The mutations p.Val336Asp, p.Trp108Arg and p.Val324fs showed $11.1 \%, 6.7 \%$ and $6.7 \%$ respectively of the allele frequency. These five mutations therefore account for approximately $70 \%$ of the mutant alleles in this gene (Table 2).

On the other hand, c.140G > A (p.Gly47Glu), c.198C >A (p.Tyr66X), c.305 T $>$ A (p.Val102Asp), c.602A $>$ T (p. Asp201Val), c.941C $>\mathrm{T}$ (p.Pro314Leu) and c.3591_382del mutations were detected as novel mutations (Fig. $2 \mathrm{a}-\mathrm{f}$ ). The first one was nonsense mutation resulting in a truncated protein, and the other four were missense mutations, while the sixth one was a small deletion (del $83 \mathrm{bp}$ ). The two mutations c.198C > A (p.Tyr66X), and c.602A > T (p. Asp201Val) were previously reported in Human Gene Mutation Database (HGMD) (http://www. hgmd.cf.ac.uk) with other variations for the same cDNA 
Table 1 Features of patients with mutation

\begin{tabular}{|c|c|c|c|c|c|c|c|c|}
\hline$\#$ & Sex & $\begin{array}{l}\text { Symptoms } \\
\text { onset age } \\
\text { Y/M }\end{array}$ & Allele 1 & Allele 2 & Initial compliant & Consanguinity & $\begin{array}{l}\text { Familial renal } \\
\text { stone history }\end{array}$ & $\begin{array}{l}\text { Urine Oxalate } \\
\text { (mg/1.73 } \\
\mathrm{m} 2 / 24 \mathrm{~h})\end{array}$ \\
\hline F1 & $\mathrm{F}$ & 15 years & $\begin{array}{l}\text { c.584 T> G } \\
\quad \text { (p.Met195Arg) }\end{array}$ & $\begin{array}{l}\text { c.584 T> G } \\
\text { (p.Met195Arg) }\end{array}$ & Trf & Yes & Yes & 70 \\
\hline F4 & $\mathrm{F}$ & 13 years & $\begin{array}{l}\text { c.33_34insC } \\
\text { (p.Lys12fs) }\end{array}$ & $\begin{array}{l}\text { c.33_34insC } \\
\text { (p.Lys12fs) }\end{array}$ & Trf & Yes & No & 55 \\
\hline F6 & $\mathrm{F}$ & 8 years & $\begin{array}{r}\text { c.33_34insC } \\
\text { (p.Lys12fs) }\end{array}$ & $\begin{array}{r}\text { c.33_34insC } \\
\text { (p.Lys12fs) }\end{array}$ & Ruti + Rf & Yes & No & 82 \\
\hline F8 & $\mathrm{F}$ & 4 years & $\begin{array}{c}\text { c.602A }>T(p . \\
\text { Asp201Val) }\end{array}$ & $\begin{array}{c}\text { c.602A > T (p. } \\
\text { Asp201Val) }\end{array}$ & Aki & Yes & No & 55 \\
\hline F9 & $\mathrm{F}$ & 8 years & $\begin{array}{l}\text { c.1007 T > A } \\
\text { (p.Val336Asp) }\end{array}$ & $\begin{array}{l}\text { c.1007 T>A } \\
\text { (p.Val336Asp) }\end{array}$ & $A k i+B k s$ & Yes & No & 45 \\
\hline F10 & $\mathrm{F}$ & 3 years & $\begin{array}{l}\text { c.941C>T } \\
\quad \text { (p.Pro314Leu) }\end{array}$ & $N$ & Ruti \& Oli & No & No & 50 \\
\hline F19 & $\mathrm{F}$ & 13 years & $\begin{array}{l}\text { c.33_34insC } \\
\text { (p.Lys12fs) }\end{array}$ & $\begin{array}{r}\text { c.33_34insC } \\
\text { (p.Lys12fs) }\end{array}$ & Ruti + Rf + Hem & No & Yes & 55 \\
\hline$F 21$ & M & $1 y$ & $\begin{array}{l}\text { c.322 T>C } \\
\text { (p.Trp108Arg) }\end{array}$ & $\begin{array}{l}\text { c.322 T>C } \\
\text { (p.Trp108Arg) }\end{array}$ & $\mathrm{Rf}$ & Yes & No & 80 \\
\hline F23 & M & 3.5 years & $\begin{array}{r}\text { c.33_34insC } \\
\text { (p.Lys12fs) }\end{array}$ & $\begin{array}{r}\text { c.33_34insC } \\
\text { (p.Lys12fs) }\end{array}$ & Ruti + Ssp & Yes & Yes & 282 \\
\hline$F 25$ & M & 7 months & $\begin{array}{l}\text { c.971-972delTG } \\
\text { (p.Val324fs) }\end{array}$ & $\begin{array}{l}\text { c.971-972delTG } \\
\text { (p.Val324fs) }\end{array}$ & Rf & Yes & No & 250 \\
\hline F28 & M & 3 months & $\begin{array}{l}\text { c.33_34insC } \\
\text { (p.Lys12fs) }\end{array}$ & $\begin{array}{r}c .1007 \mathrm{~T}>\mathrm{A} \\
\text { (p.Lys12fs) }\end{array}$ & $A n$ & Yes & Yes & 150 \\
\hline F30 & $\mathrm{F}$ & 8 months & $\begin{array}{r}\text { c.33_34insC } \\
\text { (p.Lys12fs) }\end{array}$ & $\begin{array}{r}\text { c.33_34insC } \\
\text { (p.Lys12fs) }\end{array}$ & Rf & Yes & No & 240 \\
\hline F31 & $\mathrm{F}$ & 7 months & $\begin{array}{r}\text { c.33_34insC } \\
\text { (p.Lys12fs) }\end{array}$ & $\begin{array}{r}\text { c.33_34insC } \\
\text { (p.Lys12fs) }\end{array}$ & Bneph & Yes & No & 128 \\
\hline F33 & $\mathrm{F}$ & 8 years & $\begin{array}{l}c .305 \text { T > A } \\
\text { (p.Val102Asp) }\end{array}$ & $\begin{array}{l}c .305 \text { T > A } \\
\text { (p.Val102Asp) }\end{array}$ & Ruti & Yes & Yes & 92 \\
\hline F34 & $\mathrm{F}$ & 2.5 years & $\begin{array}{l}\text { c.584T }>\text { G } \\
\text { (p.Met195Arg) }\end{array}$ & $\begin{array}{l}\text { c.584 T>G } \\
\text { (p.Met195Arg) }\end{array}$ & Ruti & Yes & Yes & 60 \\
\hline F35 & $\mathrm{F}$ & 7.5 months & $\begin{array}{l}\text { c.198C > A } \\
(\text { p.Tyr66X) }\end{array}$ & $\begin{array}{l}\text { c.198C > A } \\
(\text { p.Tyr66X) }\end{array}$ & $\operatorname{Trf}+\mathrm{An}$ & Yes & Yes & 50 \\
\hline F36 & $\mathrm{F}$ & 7 months & $\begin{array}{l}\text { c.866G > A } \\
\text { (p.Arg289His) }\end{array}$ & $\begin{array}{l}\text { c. } 866 \mathrm{G}>\mathrm{A} \\
\text { (p.Arg289His) }\end{array}$ & Trf & Yes & No & 30 \\
\hline F39 & $\mathrm{F}$ & 10 years & $\begin{array}{l}\text { c.322 T>C } \\
\quad \text { (p.Trp108Arg) }\end{array}$ & $\begin{array}{l}\text { c.322 T>C } \\
\text { (p.Trp108Arg) }\end{array}$ & $\mathrm{Rf}$ & Yes & No & 75 \\
\hline $\mathrm{F} 40$ & $\mathrm{~F}$ & 8 years & $\begin{array}{l}\text { c.508G > A } \\
\text { (p.Gly170Arg) }\end{array}$ & $\begin{array}{l}\text { c. } 997 \mathrm{~A}>\mathrm{T} \\
\quad(\operatorname{Arg} 333 \mathrm{X})\end{array}$ & Trf & No & No & 200 \\
\hline F41 & $\mathrm{F}$ & 10 months & $\begin{array}{l}\text { c.1007 T > A } \\
\text { (p.Val336Asp) }\end{array}$ & $\begin{array}{l}\text { c.1007 T > A } \\
\text { (p.Val336Asp) }\end{array}$ & Ruti & Yes & No & 130 \\
\hline F42 & M & 3.5 years & $\begin{array}{l}\text { c.584 T>G } \\
\text { (p.Met195Arg) }\end{array}$ & $\begin{array}{l}\text { c.1078C > T } \\
\text { (p.Arg360Trp) }\end{array}$ & Trf & No & Yes & 250 \\
\hline F45 & $\mathrm{F}$ & 5 months & $\begin{array}{r}\text { c.33_34insC } \\
\text { (p.Lys12fs) }\end{array}$ & $\begin{array}{l}\text { c.508G > A } \\
\text { (p.Gly170Arg) }\end{array}$ & Aki & Yes & Yes & 230 \\
\hline F48 & M & 1 months & $\begin{array}{l}\text { c.971-972delTG } \\
\text { (p.Val324fs) }\end{array}$ & $\begin{array}{l}\text { c.971-972delTG } \\
\text { (p.Val324fs) }\end{array}$ & Aki & Yes & Yes & 111 \\
\hline F49 & M & 12 years & $\begin{array}{r}\text { c.33_34insC } \\
\text { (p.Lys12fs) }\end{array}$ & $\begin{array}{r}\text { c.33_34insC } \\
\text { (p.Lys12fs) }\end{array}$ & Rf & Yes & No & 150 \\
\hline F50 & M & 4 months & $\begin{array}{r}\text { c.33_34insC } \\
\text { (p.Lys12fs) }\end{array}$ & $\begin{array}{r}\text { c.33_34insC } \\
\text { (p.Lys12fs) }\end{array}$ & Aki & Yes & Yes & 100 \\
\hline F51 & $\mathrm{F}$ & 2.5 years & $\begin{array}{l}\text { c.584 T>G } \\
\text { (p.Met195Arg) }\end{array}$ & $\begin{array}{l}\text { c.584 T>G } \\
\text { (p.Met195Arg) }\end{array}$ & Ruti + Rf & Yes & Yes & 368 \\
\hline F56 & $\mathrm{F}$ & 6 years & c.359-1_382del & c.359-1_382del & $B k s+R f$ & yes & yes & 294 \\
\hline F60 & $\mathrm{F}$ & 2 years & $\begin{array}{r}\text { c.33_34insC } \\
\text { (p.Lys12fs) }\end{array}$ & $\begin{array}{l}\text { c. } 508 \mathrm{G}>\mathrm{A} \\
\text { (p.Gly170Arg) }\end{array}$ & Bks + Ruti & No & No & 150 \\
\hline
\end{tabular}


Table 1 (continued)

\begin{tabular}{|c|c|c|c|c|c|c|c|c|}
\hline$\#$ & Sex & $\begin{array}{l}\text { Symptoms } \\
\text { onset age } \\
\text { Y/M }\end{array}$ & Allele 1 & Allele 2 & Initial compliant & Consanguinity & $\begin{array}{l}\text { Familial rena } \\
\text { stone history }\end{array}$ & $\begin{array}{l}\text { Urine Oxalate } \\
\text { (mg/1.73 } \\
\mathrm{m} 2 / 24 \mathrm{~h})\end{array}$ \\
\hline F61 & M & 5 months & $\begin{array}{l}\text { c.322 T>C } \\
\quad \text { (p.Trp108Arg) }\end{array}$ & $\begin{array}{l}\text { c.322 T>C } \\
\quad \text { (p.Trp108Arg) }\end{array}$ & $\mathrm{Rf}$ & Yes & Yes & 107 \\
\hline F65 & M & 3 months & $\begin{array}{r}\text { c.33_34insC } \\
\text { (p.Lys12fs) }\end{array}$ & $\begin{array}{l}\text { c.1007 T>A } \\
\text { (p.Val336Asp) }\end{array}$ & Aki & No & No & 90 \\
\hline F66 & $F$ & 8 years & $\begin{array}{l}\text { c.584 T > G } \\
\text { (p.Met195Arg) }\end{array}$ & $\begin{array}{l}\text { c.584 T>G } \\
\text { (p.Met195Arg) }\end{array}$ & Bks + Ruti & Yes & Yes & 297 \\
\hline F68 & $\mathrm{F}$ & 4 months & $\begin{array}{c}\text { c.33_34insC } \\
\text { (p.Lys12fs) }\end{array}$ & $\begin{array}{l}\text { c.508G > A } \\
\text { (p.Gly170Arg) }\end{array}$ & Aki & No & Yes & 75 \\
\hline F73 & M & 3 years & $\begin{array}{r}\text { c.33_34insC } \\
\text { (p.Lys12fs) }\end{array}$ & $\mathrm{N}$ & Bks & No & No & 202 \\
\hline F86 & M & $4 y$ & $\begin{array}{l}\text { c.603C > A } \\
\quad(\text { p.Asp201Glu) }\end{array}$ & $\begin{array}{l}\text { c.603C > A } \\
\text { (p.Asp201Glu) }\end{array}$ & $\mathrm{Bks}+\mathrm{Hem}$ & Yes & Yes & 100 \\
\hline F93 & M & 9 years & $\begin{array}{l}\text { c.584 T> G } \\
\text { (p.Met195Arg) }\end{array}$ & $\begin{array}{l}\text { c.584 T>G } \\
\text { (p.Met195Arg) }\end{array}$ & Trf & Yes & No & 130 \\
\hline F99 & M & 8 months & $\begin{array}{l}\text { c.33_34insC } \\
\text { (p.Lys12fs) }\end{array}$ & $\begin{array}{l}\text { c.33_34insC } \\
\text { (p.Lys12fs) }\end{array}$ & Bneph & Yes & Yes & 200 \\
\hline F100 & $\mathrm{F}$ & 7 years & $\begin{array}{r}\text { c.33_34insC } \\
\text { (p.Lys12fs) }\end{array}$ & $\begin{array}{r}\text { c.33_34insC } \\
\text { (p.Lys12fs) }\end{array}$ & Bneph & Yes & No & 150 \\
\hline F103 & M & 7 years & $\begin{array}{l}\text { c.1007 T > A } \\
\quad(p . V a l 336 \text { Asp })\end{array}$ & $\begin{array}{l}\text { c.1007 T > A } \\
\quad \text { (p.Val336Asp) }\end{array}$ & Ruti & Yes & No & 150 \\
\hline F111 & M & 13 years & $\begin{array}{l}\text { c.140G > A } \\
\text { (p.Gly47Glu) }\end{array}$ & $\begin{array}{l}\text { c.731 T>C } \\
\text { (p.lle244Thr) }\end{array}$ & Bks & Yes & Yes & 150 \\
\hline F116 & $\mathrm{F}$ & 45 years & $\begin{array}{l}\text { c.1007T>A } \\
\text { (p.Val336Asp) }\end{array}$ & $\begin{array}{l}\text { c.1007 T > A } \\
\text { (p.Val336Asp) }\end{array}$ & Bks & Yes & Yes & 125 \\
\hline F123 & M & 5 years & $\begin{array}{l}\text { c. } 198 \mathrm{C}>\mathrm{A} \\
\quad(\mathrm{p} . \mathrm{Tyr} 66 \mathrm{X})\end{array}$ & $\begin{array}{l}\text { c.198C > A } \\
\text { (p.Tyr66X) }\end{array}$ & Nakt & Yes & Yes & 80 \\
\hline F133 & M & 5 years & $\begin{array}{l}\text { c.198C > A } \\
\quad(\text { p.Tyr66X) }\end{array}$ & N & ND & No & Yes & 47 \\
\hline F134 & M & 4.5 years & $\begin{array}{l}\text { c.971-972delTG } \\
\text { (p.Val324fs) }\end{array}$ & $\begin{array}{l}\text { c.971-972delTG } \\
\text { (p.Val324fs) }\end{array}$ & Aki & Yes & Yes & 160 \\
\hline F136 & M & 4 years & $\begin{array}{r}\text { c.33_34insC } \\
\text { (p.Lys12fs) }\end{array}$ & $\begin{array}{r}\text { c.33_34insC } \\
\text { (p.Lys12fs) }\end{array}$ & $\mathrm{Rf}$ & Yes & No & 125 \\
\hline F138 & $\mathrm{F}$ & 9 years & $\begin{array}{r}\text { c.33_34insC } \\
\text { (p.Lys } 12 f s)\end{array}$ & $\begin{array}{r}\text { c.33_34insC } \\
\text { (p.Lys } 12 f s)\end{array}$ & Bneph & Yes & Yes & 246 \\
\hline$\#$ & $\begin{array}{l}\text { Blood } \\
\text { creatinine }\end{array}$ & $\begin{array}{l}\text { Calcemia } \\
\text { (mg/dl) }\end{array}$ & Urine oxalate & Urine creatinine & $\begin{array}{l}\text { Radiological } \\
\text { findings }\end{array}$ & $\begin{array}{l}\text { Additional } \\
\text { information }\end{array}$ & ESRD & Outcome \\
\hline F1 & 13 & 7 & High & 34 & Bneph & Hemdia & Yes & Died \\
\hline F4 & 11 & 7.2 & High & 21 & Bneph & Perdia & Yes & ND \\
\hline F6 & 2 & 8 & High & 11 & UL & $\mathrm{Sr}$ & No & Alive \\
\hline F8 & 3.7 & 6.6 & High & 13 & Bneph & ND & Yes & ND \\
\hline F9 & 10 & 9.9 & High & 10 & UL & ND & Yes & Died \\
\hline F10 & 0.4 & 8 & High & 18 & UL & ND & $?$ & ND \\
\hline F19 & 5.6 & 6 & High & 16.5 & UL & ND & Yes & Alive \\
\hline F21 & 1.5 & 7.7 & High & 12 & Bneph & ND & No & ND \\
\hline F23 & 0.6 & 8.4 & High & 35 & UL+Bneph & $\mathrm{Cm}$ & No & Alive \\
\hline F25 & 9 & 9.6 & High & 43 & Bneph & Perdia & Yes & Died \\
\hline F28 & 7 & 8.5 & High & 12 & Bneph & ND & Yes & Died \\
\hline F30 & 8.9 & 7.3 & High & 23 & Bneph & ND & Yes & Died \\
\hline F31 & 0.82 & 9.7 & High & 13 & Bneph & $\mathrm{Cm}$ & No & Alive \\
\hline F33 & 0.6 & 9.2 & High & 8 & UL & $\mathrm{Cm}$ & No & Alive \\
\hline F34 & 0.76 & 10 & High & 11 & Bneph & ND & No & ND \\
\hline F35 & 8.3 & 9.2 & High & 15 & Bneph & Perdia & Yes & Died \\
\hline
\end{tabular}


Table 1 (continued)

\begin{tabular}{|c|c|c|c|c|c|c|c|c|}
\hline \# & $\begin{array}{l}\text { Blood } \\
\text { creatinine }\end{array}$ & $\begin{array}{l}\text { Calcemia } \\
\text { (mg/dl) }\end{array}$ & Urine oxalate & Urine creatinine & $\begin{array}{l}\text { Radiological } \\
\text { findings }\end{array}$ & $\begin{array}{l}\text { Additional } \\
\text { information }\end{array}$ & ESRD & Outcome \\
\hline F36 & 6.7 & 7 & Normal & 10 & UL+Bneph & Perdia & Yes & ND \\
\hline F39 & 1 & 5 & High & 15 & Bneph & Perdia & No & ND \\
\hline F40 & 10 & 8 & High & 10 & Bneph & Perdia & No & ND \\
\hline F41 & 0.7 & 12 & High & 19 & Bneph & Hemdia & No & ND \\
\hline F42 & 2.5 & 11 & High & 22 & UL & Perdia & No & ND \\
\hline F45 & 9 & 9.5 & High & 15 & Bneph & Hemdia & Yes & ND \\
\hline F48 & 4.3 & 8.5 & High & 10 & Bneph & Hemdia & Yes & Died \\
\hline F49 & 5 & 8 & High & 12 & Bneph & $\mathrm{Cm}$ & Yes & Alive \\
\hline F50 & 14 & 8.5 & High & 15 & Bneph & ND & Yes & Died \\
\hline F51 & 5.3 & 7.9 & High & 24 & Bneph & Perdia & Yes & Died \\
\hline F56 & 3.5 & 7 & High & 10 & Bneph & $\mathrm{Cm}$ & Yes & Alive \\
\hline F60 & 0.6 & 10 & High & 6.5 & Bneph & Perdia & NO & Alive \\
\hline F61 & 4 & 9 & High & 15 & Bneph & $\mathrm{Cm}$ & Yes & Died \\
\hline F65 & 8.9 & 8 & High & 20 & Bneph & $\mathrm{Cm}$ & Yes & ND \\
\hline F66 & 1.4 & 9 & High & 20 & UL & Hemdia & No & Alive \\
\hline F68 & 3.5 & 7.8 & High & 16 & Bneph & ND & Yes & Died \\
\hline F73 & 0.38 & 9.5 & High & 20 & UL & Perdia & No & Alive \\
\hline F86 & 0.7 & 10 & High & 22 & UL & Perdia & No & Alive \\
\hline F93 & 9.6 & 8.7 & High & 15 & Bneph & Hemdia & Yes & Died \\
\hline F99 & 0.8 & 8.5 & High & 15 & Bneph & Perdia & No & Alive \\
\hline F100 & 0.9 & 9 & High & 24 & Bneph & Perdia & No & ND \\
\hline F103 & 0.9 & 9 & High & 24 & Bneph & $\mathrm{Cm}$ & No & Alive \\
\hline F111 & 4 & 9.5 & High & 25 & Bneph & Hemdia & Yes & Alive \\
\hline F116 & 4 & 8 & High & 15 & Bneph & Drakt & Yes & Alive \\
\hline F123 & 1.7 & 10 & High & 67 & Bneph & $\mathrm{Cm}$ & Yes & Alive \\
\hline F133 & 3.7 & 8 & Normal & 44 & Bneph & ND & Yes & Alive \\
\hline F134 & 0.74 & 8.8 & High & 30 & Bneph & $\mathrm{Cm}$ & no & Alive \\
\hline F136 & 1.4 & 9.1 & High & 15 & Bneph & $\mathrm{Cm}$ & No & Alive \\
\hline F138 & 1 & 10.6 & High & 28 & Bneph & ND & Yes & ND \\
\hline
\end{tabular}

Trf terminal renal failure; An Anuria, Ruti recurrent urinary tract infection, Rf renal failure, Aki acute kidney injury, Bks bilateral kidney stones, Oli oliguria, Hem hematuria, Ssp spontaneous stone passage, Nakt nephrocalcinosis after kidney transplantation, Hemdia hemodialysis, Perdia peritoneal dialysis, Sr stone resection, $\mathrm{Cm}$ conservative management, Drakt disease recurrence after kidney transplant, Bneph bilateral nephrocalcinosis, UL urolithiasis, ESRD end stage renal disease, Min miner, Maj major, ND no data aviable

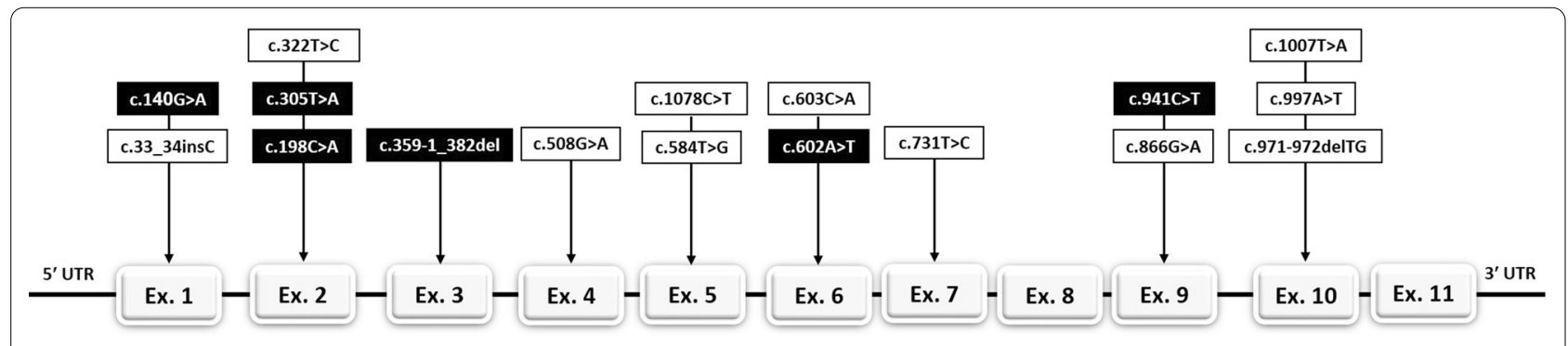

Fig. 1 Schematic representation of the AGXT gene with the localization of the mutations found in this study

position. The rest of mutations have not been previously described in the HGMD or the PH Mutation Database [14]. Mutations of patients are summarized in Tables 1.

\section{Polymorphisms and haplotype analysis}

Haplotype analysis performed based on sequencing data for 11 SNPs (Table 3). The analysis showed that 
Table 2 Results of molecular analysis for DNA from $45 \mathrm{PH}-1$ Syrian patients

\begin{tabular}{lrlll}
\hline Mutation & Exon & Maj/min & $\begin{array}{l}\text { Number of } \\
\text { alleles }\end{array}$ & $\begin{array}{l}\text { Allele } \\
\text { frequency } \\
\text { (\%) }\end{array}$ \\
\hline c.33_34insC & 1 & Maj & 30 & 33.3 \\
c.584T>G & 5 & Min & 11 & 12.2 \\
c.1007T > A & 10 & Min & 10 & 11.1 \\
c.322T >C & 2 & Min & 6 & 6.7 \\
c.971-972delTG & 10 & Maj & 6 & 6.7 \\
c.198C > A & 2 & Maj & 5 & 5.6 \\
c.508G > A & 4 & Min & 4 & 4.4 \\
c.305T>A & 2 & Min & 2 & 2.2 \\
c.602A > T & 6 & Min & 2 & 2.2 \\
c.866G > A & 9 & Maj & 2 & 2.2 \\
c.603C > A & 6 & Maj & 2 & 2.2 \\
c.359-1_382del & 3 & Maj & 2 & 2.2 \\
c.731 T>C & 7 & Min & 1 & 1.1 \\
c.140G > A & 1 & Min & 1 & 1.1 \\
c.941C > T & 9 & Min & 1 & 1.1 \\
c.1078C > T & 11 & Maj & 1 & 1.1 \\
c.997A $>$ T & 10 & Maj & 1 & 1.1 \\
\hline
\end{tabular}

some mutations segregate with a specific genotypic combination. Minor allele (p.P11L, p.I340M and 74-bp duplication in intron1) and the three polymorphisms c. $165+16 \mathrm{~A}>\mathrm{G}$ (rs66494441) in intron 1, p.Ala88Ala (rs35698882) in Exon 2, and c.358 $+13 \mathrm{C}>\mathrm{T}$ (rs34995778) in intron 2 co-segregated with the four mutations p.Val102Asp, p.Trp108Arg, p.Val336Asp and p.Met195Arg. Additional variations, p.Asn22Ser (rs34885252), c.423+29C $>\mathrm{T}$ (rs117043148) and the c. ${ }^{*} 41 \mathrm{C}>\mathrm{A}$ (rs4273214) were associated with the p. Asp201Val mutation.

On the other hand, the c.359-1_382del and p.Lys12fs mutations co-segregated with the major allele. We noted also that, intronic polymorphisms c. $595+100 \mathrm{G}>\mathrm{A}$ (rs12997245) in introns 5 is linked with the p.Arg289His, p.Val324fs and p.Tyr66X mutations. In addition, the polymorphism p.Ser218Ser (rs33958047) in exon 6 linked with the p.Asp201Glu mutation. Furthermore, the c. $* 41 \mathrm{C}>\mathrm{A}$ in coding region 3'UTR was associated with the p. Asp201Val and p.Arg 289 His mutations. These results revealed the founder nature of the reported mutations.

\section{Discussion}

$\mathrm{PH}-1$ is a rare, recessive, inherited inborn error of glyoxylate metabolism. It remains underdiagnosed because of the large variability in its clinical presentation and age of onset. For that, all patients with recurrent nephrocalcinosis or nephrolithiasis should be evaluated for PH-1 [15].

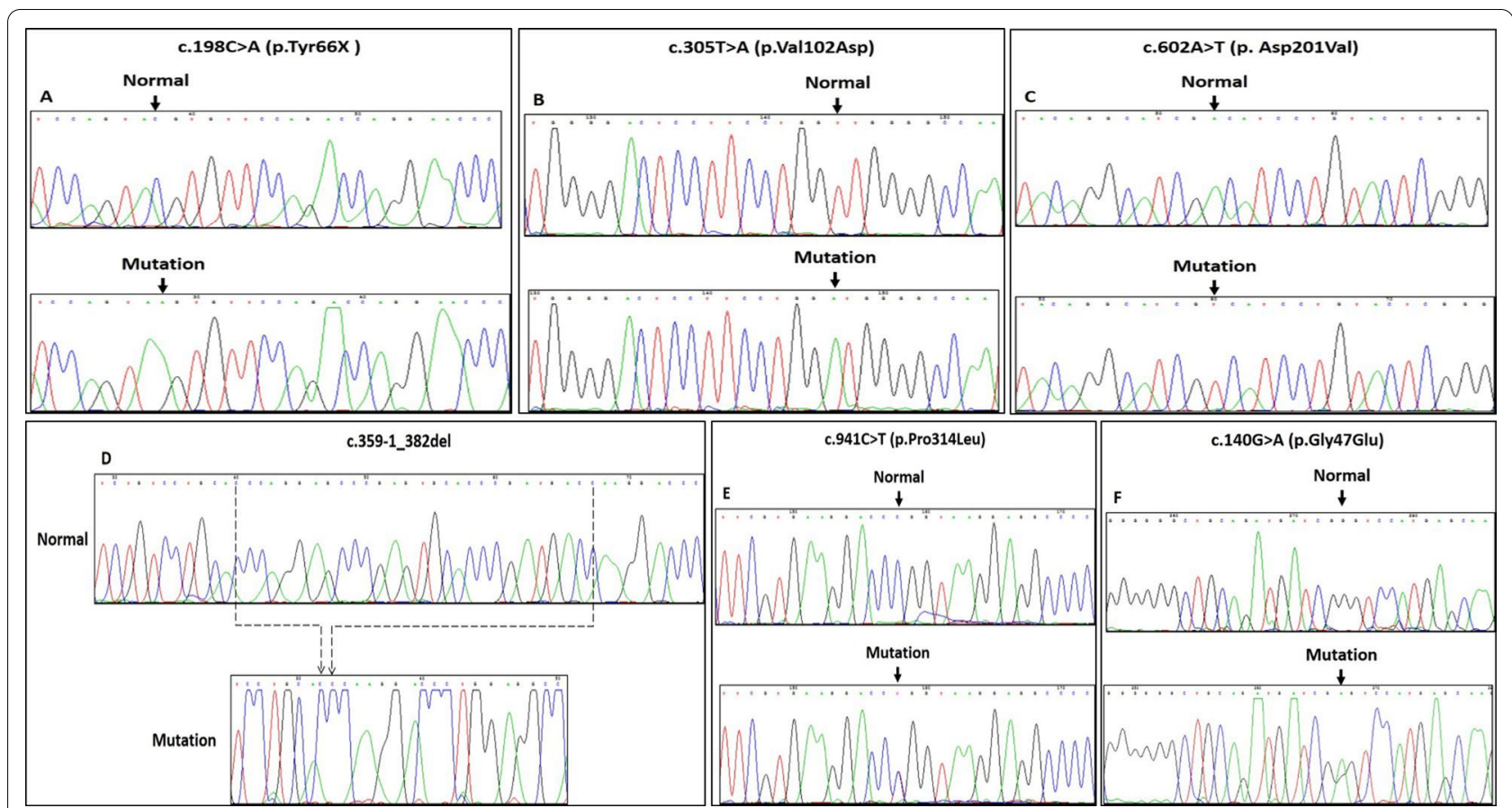

Fig. 2 a-f Sequence chromatograms of the c.198C > A (p.Tyr66X), c.305 T > A (p.Val102Asp), c.602A > T (p. Asp201Val), c.359-1_382del, c.941C >T (p.Pro314Leu) and c.140G > A (p.Gly47Glu) mutations in the AGXT gene. Arrow shows the sequence change 


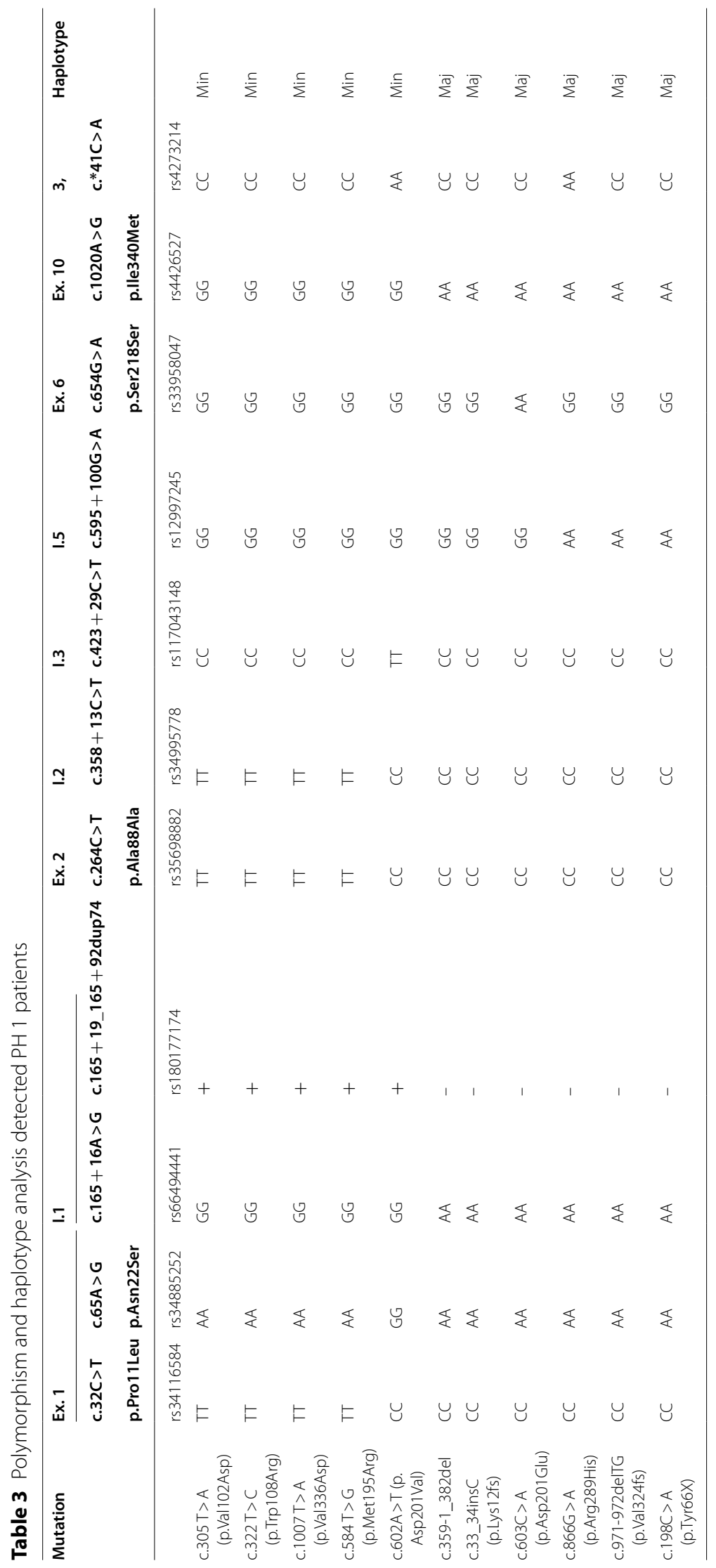


High rates of consanguinity in Middle East countries had a clear effect in increasing the frequency of patients with PH-1[10, 12, 13, 15].

This is the first study about the mutational screening for $\mathrm{PH}-1$ among Syrian children. In our 45 patients, the diagnosis of PH-1 was initially based on clinical findings, elevated plasma oxalate, urine analysis (raised oxalate), and spectrophotometric analysis of the calculation urine showing a pure calcium oxalate monohydrate (whewellite).

Previous studies reported that mutations found in exons $1,2,5,7$ and 10 are responsible for $70 \%$ of $\mathrm{PH}-1$ patients in Arab population [10, 12, 13]. Therefore, these five exons were firstly screened by DNA sequencing.

This approach allowed us to identify genetic basis in 37 patients $(37 / 45 ; 82.22 \%)$, the remaining patients $(8 / 45$; $17.77 \%$ ), we tested exons $3,4,6,8,9$ and 11 of the AGXT gene.

In our study, among the 45 patients in Syria, we found 17 different mutations in the AGXT gene that cause $\mathrm{PH}-1$. This result confirms the high degree of genetic heterogeneity in this disease. Six of these mutations (c.140G > A, c.198C >A, c.305 T >A, c.602A > T, c.941C $>$ T and c.359-1_382del) have not been previously reported. The vast majority of the patients were homozygous for their mutations, as could be expected in a highly consanguineous community. Identification of molecular bases in all investigated $\mathrm{PH}-1$ patients allowed us to propose a mutational screening strategy for the Syrian population.

c.33_34insC (p.Lys12fs) was the most frequently detected mutation in our study. c.33_34insC is a mutation that generates a stop codon, which leads to the formation of a truncated protein [16]. This duplication is spread in many ethnic and geographic regions in the world, and its high frequency could probably be attributed to multiple mutations in the region of eight cytosine repeat sequences where it occurs.

The second most common mutation found was the c.584 T $>$ G (p.Met195Arg) mutation (12.2\%), which is a mutation in a well conserved region of exon 5 . This sequence change replaces methionine with arginine at codon 195 of the AGXT protein (p.Met195Arg). Some individuals affected with primary hyperoxaluria, type 1 had this variant [17-19]. This variant has been described to affect AGXT protein function [20]. Prediction software estimated that this variant may create or strengthen a splice site, but this estimation has not been confirmed. For these causes, the c.584 $\mathrm{T}>\mathrm{G}$ variant has been known as Pathogenic.

The c.1007 T > A (p.Val336Asp) is the third most common mutation in our cohort (11.1\%). Most patients affected by this mutation were in a homozygous condition, only two were heterozygous. This mutation results in the amino acid replacement Val336Asp. The mutation was present on the minor allele and in combination with the frequent c.33_34insC (p.Lys12fs). The Val336Asp mutation appears to affect in a negative way with the effect of pyridoxine, and in fact, prompts the development of renal insufficiency, at least in homozygous patients [7].

The c.322 T > C (p.Trp108Arg) mutation was found in $6.7 \%$ of our cohort. It was identified in a homozygous state in our patients. This sequence change replaces tryptophan with arginine at codon 108 of the AGXT protein (p.Trp108Arg). This variant is observed in many individuals affected with AGXT-related conditions [17, 21]. This variant has been known to affect AGXT protein function $[20,22,23]$. For these causes, this variant has been considered as Pathogenic.

In addition, the c.971-972delTG (p.Val324fs) mutation was reported with $6.7 \%$ of allele frequency in three patients. It was identified in a homozygous state. It was associated with the Maj allele. This variation was reported without exact frequencies or origin of patients [6].

The AGXT c.508G > A (p.Gly170Arg) variant (4.4\%) is previously well defined as one of the most common variants associated with primary hyperoxaluria type $1[9,24$, 25]. It was identified in our cohort in a compound heterozygous state with two different mutations c.997A $>\mathrm{T}$ (Arg333X), and c.33_34insC (p.Lys12fs), and no patients were reported to be homozygous for this mutation. Functional studies confirm that the G170R variant is linked with mistargeting of the AGT enzyme to the mitochondria more than to the peroxisomes [26]. On the other hand, several studies informed that, patients with G170R mutation may have longer preservation of renal function with conventional treatment compared to other pathogenic mutations and respond to pyridoxine treatment which is a cofactor that reduces enzyme mistargeting [27-29].

The c.866G $>$ A (p.Arg289His) and c.603C $>$ A (p.Asp201Glu) mutations were found in a homozygous state in $2.2 \%$ of cases. The two mutations co-segregate with the Min allele.

The c.866G > A variant has been reported as a part of two complex alleles in patients with Primary Hyperoxaluria Type $1[6,30]$. On the other hand, the variant c.603C > A (p.Asp201Glu) has been detected in many individuals and families affected with hyperoxaluria [9, $27,30]$. This variant causes a replacement of aspartic acid residue by glutamic acid residue at codon 201 of the AGXT protein (p.Asp201Glu). This variant has been known to affect AGXT protein function [20]. For these reasons, this variant has been predicted as Pathogenic. 


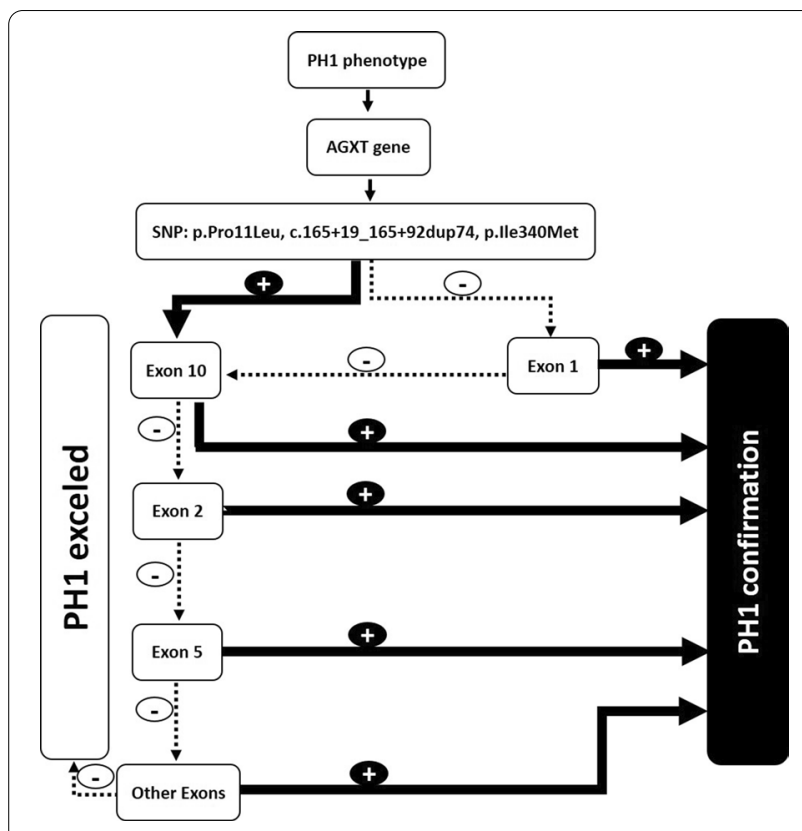

Fig. 3 Decisional tree for molecular diagnosis of $\mathrm{PH}-1$ in Syria. SNPs: single nucleotide polymorphisms

The mutation c.603C > A (p.Asp201Glu) replaces aspartic acid with glutamic acid at codon 201 of the AGXT protein (p.Asp201Glu). This variant has been detected in some individuals and families affected with hyperoxaluria $[9,27,30,31]$. This variant has been described to affect AGXT protein function, and it is considered as Pathogenic [20].

In contrast to the Arab Maghreb countries, which have the p.I244T mutation (Maghrebian mutation) as the most frequent mutation $[12,21]$, this mutation was detected in our study in only one patient as a heterozygous state combined with the new mutation $(\mathrm{c} .140 \mathrm{G}>\mathrm{A})$ at a frequency $(1.1 \%)$.

The c.1078C $>\mathrm{T}$ (p.Arg360Trp) mutation was found in our cohort as a heterozygous state with c.584 T>G, it was associated with the Major allele. The Bioinformatics prediction program MutationTaster (www.mutat iontaster.org), estimated the mutation c.1078C $>\mathrm{T}$ (p.Arg360Trp) to be disease causing [32]. We expect the mutation c.1078C > T (p.Arg360Trp) to be pathogenic as previously described [29].

The Exon 10 mutation c.997A > T (p.Arg333X) results in a premature termination codon (TGA) replacing a codon for amino acid 333 [33]. It was found in our cohort in a heterozygous state with c.508G > A mutations.

The mutation c.602A > T (p. Asp201Val) has not yet been defined in patients with primary hyperoxaluria type
I. However, a mutation c.603C $>$ A (p.Asp201Glu) at the same codon 201 leading to a different amino acid substitution has been found in patients with primary hyperoxaluria type I. furthermore the mutation c.602A $>\mathrm{T}$ (p. Asp201Val) is not annotated as single nucleotide polymorphism (SNP) in any database.

The new variant c.198C > A (p.Tyr66X) has not yet been previously described in patients with $\mathrm{PH}-1$, while, a mutation c.198C > G (p.Tyr66X) at the same cDNA position already described [8]. The two mutations result in a premature termination codon (TAA) replacing a codon for amino acid 66.

In the other hand, the same finding was observed for the new variant c.140G >A (p.Gly47Glu) which has not yet been formerly defined in patients with PH-I. While, a mutation c.139G > A (p.Gly47Arg) at the same codon 47 was already known as pathogenic mutation [9]. The two mutations co-segregate with the Min allele, and the bioinformatics prediction program MutationTaster, estimated the mutation c.140G > A (p.Gly47Glu) to be disease causing.

In addition, the c.941C $>\mathrm{T}$ (p.Pro314Leu) mutation was reported with $1.1 \%$ of allele frequency in only one patient with heterozygous state. It was associated with the miner allele. This variation is a substitution in exon 9 for $C$ to $T$ at position 941, encoding a Pro to Leu substitution at residue 314. This variation was only reported in the ExAC database (http://exac.broadinstitute.org) as pathogenic mutation.

Finally, the, c.305 T>A (p.Val102Asp), mutation was identified in exon 2. It was founded in a homozygous state. In fact, the missense mutation (c.305 $\mathrm{T}>\mathrm{A}$ ) was not previously reported in any genome database. It was reported in this study for the first time, it was associated with the Miner allele. Analysis with MutationTaster predicted program estimated that the mutation was damaging mutations. On the other hand, the c.359-1_382del mutation was identified in exon 3. It was also founded in homozygous states. The (c.359-1_382del) mutation was previously described in Rumsby as an unpublished data [14].

The heterozygous only for one allele was detected in three patients. An AGXT MLPA was recommended in these patients in order to detect a huge insertion/deletion. In addition, complete sequencing of all known causative genes affecting glyoxylate metabolism should be considered.

\section{Limitation}

The limitations of this study is that it is lacking in functional studies, which is necessary in order to be completely sure of the phenotypic effects of the new mutations. 
In the other hand, some clinical information for some patients are unfortunately not available for us due to the current situation in Syria. Consequently, we were unable to present the full clinical information for some patient's as required for these kinds of studies.

\section{Conclusion}

$\mathrm{PH}-1$ is known as a clinically and genetically heterogeneous syndrome. We report here by our experience the AGXT gene mutation analysis in 45 unrelated probands with a definitive diagnosis of PH-1. DNA sequencing method was used for exon 1 essentially and then for exons 10, 2 and 5 of the AGXT gene. This technique can provide a useful, cost-effective process in Syrian PH-1 patients (Fig. 3). Molecular diagnosis of $\mathrm{PH}-1$ in our country may be accomplished by following this process and would permit an accurate method for a precocious diagnosis in Syrian affected families (even without a clinical subtyping of $\mathrm{PH}$ ) and detection of presymptomatic individuals. This will also avoid rapid progression to renal failure.

\section{Abbreviations}

$\mathrm{PH}-1$ : primary hyperoxaluria type 1; AGXT: alanine glyoxylate aminotransferase; Maj: major; Min: minor.

\section{Acknowledgements}

We thank Dr. I. Othman, Director General of The Atomic Energy Commission of Syria (AECS), and Dr. N. Mirali, Head of Molecular Biology and Biotechnology Department for their support and Miss S. Tez for kind technician assistant. This work was supported by the AECS.

\section{Authors' contributions}

HM, MBA, AD, NA and MSN worked on this manuscript and did all of the researching groundwork. $Y Z$ and HW ensured a regular clinical follow up of the family, carried out the biochemical analyses and collected the blood samples and drafted the manuscript. All authors read and approved the final manuscript.

\section{Funding}

No funding was received.

\section{Availability of data and materials}

The datasets generated and analysed during the current study for the Primary hyperoxaluria type 1 are available in the NCBI (accession number: (MIM 259900), https://www.ncbi.nlm.nih.gov/gene/?term=MIM\%20259900). The web links of the relevant datasets were as follows: dbSNP (http://www.bioin fo.org.cn/relative/dbSNP\%20Home\%20Page.htm), ClinVar (https://www. ncbi.nlm.nih.gov/clinvar/), HGMD (http://www.hgmd.cf.ac.uk/ac/index.php), MutationTaster (www.mutationtaster.org), ExAC database (http://exac.broad institute.org).

\section{Declarations}

\section{Ethics approval and consent to participate}

This study was approved by the Ethics Committee of Atomic Energy Commission of Syria, and informed consent was obtained from parents for minors and from all adult patients.

\section{Consent for publication}

Written consent was obtained from parents for minors and from all adult patients for publication of this manuscript and any accompanying images.

\section{Competing interests}

The authors declare that they have no competing interests.

\section{Author details}

${ }^{1}$ Human Genetics Division, Molecular Biology and Biotechnology Department, Human Genetics Division, Atomic Energy Commission of Syria, P.O. Box 6091, Damascus, Syria. ${ }^{2}$ Chlidien's Hospital of Damascus, Damascus, Syria.

Received: 15 February 2021 Accepted: 27 May 2021

Published online: 03 June 2021

\section{References}

1. Cochat P, Deloraine A, Rotily M, Olive F, Liponski I, Deries N. Epidemiology of primary hyperoxaluria type 1. Société de Néphrologie and the Société de Néphrologie Pédiatrique. Nephrol Dial Transplant. 1995;10(Suppl 80):3-7.

2. Danpure CJ. Primary hyperoxaluria type 1: AGT mistargeting highlights the fundamental differences between the peroxisomal and mitochondrial protein import pathways. Biochim Biophys Acta. 2006;1763:1776-84.

3. Coulter-Mackie MB, Rumsby G, Applegarth DA, Toone JR. Three novel deletions in the alanine:glyoxylate aminotransferase gene of three patients with type 1 hyperoxaluria. Mol Genet Metab. 2001;74:314-21.

4. Harambat J, Fargue S, Bacchetta J, Acquaviva C, Cochat P. Primary hyperoxaluria. Int J Nephrol. 2011;2011:864580.

5. Milliner DS, Harris PC, Cogal AG, Lieske JC. Primary hyperoxaluria type 1. In: GeneReviews $\left({ }^{\circledR}\right)$. Edited by Adam MP, Ardinger HH, Pagon RA, Wallace SE, Bean LJH, Stephens K, Amemiya A. Seattle (WA): University of Washington, Seattle Copyright (c) 1993-2020, University of Washington, Seattle. GeneReviews is a registered trademark of the University of Washington, Seattle. All rights reserved.; 1993.

6. Williams EL, Acquaviva C, Amoroso A, Chevalier F, Coulter-Mackie M, Monico CG, Giachino D, Owen T, Robbiano A, Salido E, et al. Primary hyperoxaluria type 1: update and additional mutation analysis of the AGXT gene. Hum Mutat. 2009;30:910-7.

7. van Woerden CS, Groothoff JW, Wijburg FA, Annink C, Wanders RJ, Waterham HR. Clinical implications of mutation analysis in primary hyperoxaluria type 1. Kidney Int. 2004;66:746-52.

8. Purdue PE, Lumb MJ, Allsop J, Danpure CJ. An intronic duplication in the alanine: glyoxylate aminotransferase gene facilitates identification of mutations in compound heterozygote patients with primary hyperoxaluria type 1. Hum Genet. 1991;87:394-6.

9. Monico CG, Rossetti S, Schwanz HA, Olson JB, Lundquist PA, Dawson DB, Harris PC, Milliner DS. Comprehensive mutation screening in 55 probands with type 1 primary hyperoxaluria shows feasibility of a gene-based diagnosis. J Am Soc Nephrol. 2007;18:1905-14.

10. Rhuma NR, Fituri OA, Sabei LT. Mutational analysis of AGXT gene in Libyan children with primary hyperoxaluria type 1 at Tripoli Children Hospital. Saudi J Kidney Dis Transpl. 2018;29:30-8.

11. Kalfon L, Weissman I, Hershkovits M, Nasser Samra N, Edri N, Khayat M, Tanus M, Shihab S, Mandel H, Falik-Zaccai T. Oxalate stones are prevalent among Druze and Muslim Arabs in the Galilee. Harefuah. 2017;156:156-62.

12. Boualla L, Tajir M, Oulahiane N, Lyahyai J, Laarabi FZ, Chafai Elalaoui S, Soulami K, Ait Ouamar H, Sefiani A. AGXT gene mutations and prevalence of primary hyperoxaluria type 1 in Moroccan population. Genet Test Mol Biomark. 2015;19:623-8.

13. Nagara M, Tiar A, Ben Halim N, Ben Rhouma F, Messaoud O, Bouyacoub Y, Kefi R, Hassayoun S, Zouari N, Ben Ammar MS, et al. Mutation spectrum of primary hyperoxaluria type 1 in Tunisia: implication for diagnosis in North Africa. Gene. 2013;527:316-20.

14. Rumsby G: Primary hyperoxaluria mutation database. 2013.

15. Al Riyami MS, Al Ghaithi B, Al Hashmi N, Al Kalbani N. Primary hyperoxaluria type 1 in 18 children: genotyping and outcome. Int J Nephrol. 2015;2015:634175.

16. Williams EL, Kemper MJ, Rumsby G. A de novo mutation in the AGXT gene causing primary hyperoxaluria type 1. Am J Kidney Dis. 2006:48:481-3

17. Frishberg Y, Rinat C, Shalata A, Khatib I, Feinstein S, Becker-Cohen R, Weismann I, Wanders RJA, Rumsby G, Roels F, Mandel H. Intra-familial clinical 
heterogeneity: absence of genotype-phenotype correlation in primary hyperoxaluria type 1 in Israel. Am J Nephrol. 2005;25:269-75.

18. Mandrile G, van Woerden CS, Berchialla P, Beck BB, Acquaviva Bourdain C, Hulton SA, Rumsby G, OxalEurope C. Data from a large European study indicate that the outcome of primary hyperoxaluria type 1 correlates with the AGXT mutation type. Kidney Int. 2014;86:1197-204.

19. Stern R, Kuo V, Rogal S, Barron C, Ahmed R, Goldwasser B. A case of failure to thrive secondary to primary hyperoxaluria type 1. Radiol Case Rep. 2020:15:1806-8.

20. Lage MD, Pittman AM, Roncador A, Cellini B, Tucker CL. Allele-specific characterization of alanine: glyoxylate aminotransferase variants associated with primary hyperoxaluria. PLoS ONE. 2014;9:e94338.

21. M'Dimegh S, Omezzine A, M'Barek I, Moussa A, Mabrouk S, Kaarout H, Souche G, Chemli J, Aloui S, Aquaviva-Bourdain C, et al. Mutational analysis of Agxt in Tunisian population with primary hyperoxaluria type 1. Ann Hum Genet. 2017:81:1-10.

22. Oppici E, Montioli R, Lorenzetto A, Bianconi S, Borri Voltattorni C, Cellini B. Biochemical analyses are instrumental in identifying the impact of mutations on holo and/or apo-forms and on the region(s) of alanine:glyoxylate aminotransferase variants associated with primary hyperoxaluria type I. Mol Genet Metab. 2012;105:132-40.

23. Coulter-Mackie MB, Lian Q. Partial trypsin digestion as an indicator of misfolding of mutant alanine: glyoxylate aminotransferase and chaperone effects of specific ligands. Study of a spectrum of missense mutants. Mol Genet Metab. 2008;94:368-74.

24. Coulter-Mackie MB, Applegarth D, Toone JR, Henderson H. The major allele of the alanine: glyoxylate aminotransferase gene: seven novel mutations causing primary hyperoxaluria type 1. Mol Genet Metab. 2004:82:64-8.

25. Benhaj Mbarek I, Abroug S, Omezzine A, Zellama D, Achour A, Harbi A, Bouslama A. Selected AGXT gene mutations analysis provides a genetic diagnosis in $28 \%$ of Tunisian patients with primary hyperoxaluria. BMC Nephrol. 2011;12:25.

26. Lumb MJ, Danpure CJ. Functional synergism between the most common polymorphism in human alanine:glyoxylate aminotransferase and four of the most common disease-causing mutations. J Biol Chem. 2000;275:36415-22.

27. Monico CG, Olson JB, Milliner DS. Implications of genotype and enzyme phenotype in pyridoxine response of patients with type I primary hyperoxaluria. Am J Nephrol. 2005;25:183-8.

28. Harambat J, Fargue S, Acquaviva C, Gagnadoux MF, Janssen F, Liutkus A, Mourani C, Macher MA, Abramowicz D, Legendre C, et al. Genotypephenotype correlation in primary hyperoxaluria type 1: the p.Gly170Arg AGXT mutation is associated with a better outcome. Kidney Int. 2010;77:443-9.

29. Hopp K, Cogal AG, Bergstralh EJ, Seide BM, Olson JB, Meek AM, Lieske JC, Milliner DS, Harris PC, Rare Kidney Stone C. Phenotype-genotype correlations and estimated carrier frequencies of primary hyperoxaluria. J Am Soc Nephrol. 2015:26:2559-70.

30. Williams EL, Bagg EA, Mueller M, Vandrovcova J, Aitman TJ, Rumsby G. Performance evaluation of Sanger sequencing for the diagnosis of primary hyperoxaluria and comparison with targeted next generation sequencing. Mol Genet Genom Med. 2015;3:69-78.

31. Beck BB, Baasner A, Buescher A, Habbig S, Reintjes N, Kemper MJ, Sikora P, Mache C, Pohl M, Stahl M, et al. Novel findings in patients with primary hyperoxaluria type III and implications for advanced molecular testing strategies. Eur J Hum Genet. 2013;21:162-72.

32. Schwarz JM, Cooper DN, Schuelke M, Seelow D. MutationTaster2: mutation prediction for the deep-sequencing age. Nat Methods. 2014;11:361-2.

33. Rinat C, Wanders RJ, Drukker A, Halle D, Frishberg Y. Primary hyperoxaluria type I: a model for multiple mutations in a monogenic disease within a distinct ethnic group. J Am Soc Nephrol. 1999;10:2352-8.

\section{Publisher's Note}

Springer Nature remains neutral with regard to jurisdictional claims in published maps and institutional affiliations.
Ready to submit your research? Choose BMC and benefit from:

- fast, convenient online submission

- thorough peer review by experienced researchers in your field

- rapid publication on acceptance

- support for research data, including large and complex data types

- gold Open Access which fosters wider collaboration and increased citations

- maximum visibility for your research: over $100 \mathrm{M}$ website views per year

At BMC, research is always in progress.

Learn more biomedcentral.com/submissions 